\title{
Možnosti hodnocení elektronických studijních opor ${ }^{1}$ Options for evaluating electronic learning supports

\author{
Milan Klement
}

\begin{abstract}
Anotace: Článek představuje postup ověřování a optimalizace systému hodnocení elektronických studijních opor na základě realizovaného výzkumného šetření. V rámci realizovaného výzkumného šetření bylo třeba použít vícerozměrných statistických metod faktorové a shlukové analýzy. Realizované výzkumné šetření proto bylo realizováno jako vícefázové. První dvě fáze výzkumu byly zaměřeny na ověřování systému hodnocení elektronických studijních opor, s využitím faktorové a shlukové analýzy. Třetí a čtvrtá fáze výzkumu byla zaměřena na optimalizaci systému hodnocení pomocí vícerozměrných a parametrických statistických metod.
\end{abstract}

Klíčová slova: elektronická studijní opora, distanční výuka, e-learning, hodnocení, hodnotící kritéria, faktorová analýza, shluková analýza, systém hodnocení

\begin{abstract}
The paper presents the procedure for verifying and optimizing electronic learning supports' evaluation system in virtue of a research investigation performed.

As part of the research investigation realized, it was necessary to use multidimensional statistical techniques of factor and cluster analyses. The research investigation performed was therefore conceived as multi-phase. The first two phases of the research were focused on verifying the electronic learning supports' evaluation system, using factor and cluster analyses. The third and fourth phases of the research were aimed at optimizing the system of evaluation by means of multidimensional and parametric statistical methods.
\end{abstract}

Keywords: electronic learning support, distance learning, e-learning, assessment, evaluation criteria, factor analysis, cluster analysis, evaluation system

\section{1 Úvod}

Podle moderního př́stupu uplatňovaného při evaluaci e-learningových kurzů či studijních textů ,jsou dvě velmi důležitá kritéria pro kvalitu e-learningu: musí fungovat bez problémů pro všechny účastníky po technické stránce a musí zde být jasné uplatnění pedagogických principů“ (Eger, 2004). Moderní informační a komunikační technologie ale umožňují daleko širší možnosti uplatnění didaktických principů než v minulosti. Do popředí zájmu učitelů a studentů se tak dostává vzdělávací obsah, jehož nositelem již není pouhý text a statická obrazová informace, ale dynamická obrazová informace, animace, simulace či dokonce virtuální realita (Marešová, 2009).

\footnotetext{
${ }^{1}$ Příspěvek vznikl za podpory GAČR v rámci řešení projektu č. P407/11/1306 („Evaluace vzdělávacích materiálů určených pro distanční vzdělávání a e-learning“, řešitel: PhDr. Milan Klement, Ph.D.).
} 


\section{Současné přístupy k evaluaci distančních či e-learningových kurzů}

Klasické pojetí evaluace vzdělávacích kurzů, ve své době také označovaných jako „školící programy“،, vycházela z Kirkpatrickova čtyřstupňového modelu. Čtyři stupně modelu vzdělávacího hodnocení byly později přepracovány a aktualizovány v knize z roku 1993 nazvané Evaluating Training Programs: The Four Levels (Kirkpatrick, 1993). Tento doposud uplatňovaný systém hodnocení efektivity e-learningových kurzů tedy vychází ze základního postulátu distančního vzdělávání, že toto vzdělávání je vzděláváním dospělých a může tedy být uplatňováno nejen ve firemní sfére, ale také ve sféře terciálního a celoživotního vzdělávání (Bednaříková, 2008). Jiné systémy se potom opírají o kvalitativní pojetí evaluace jako nové strategické filosofie podnikového řízení. Pojem řízení celkové kvality - Total Quality Management - (Blecharz \& Zindulková, 2005). Díky projektům jako např. SEEQUEL již existují Koncepce kvality v e-learningu (Seequel, 2004) nebo Obecný rámec kvality v e-learningu (Anderson \& McCormic, 2005) a postupně se tak konstituuje systém ř́zení kvality v e-learningu. Existuje tedy více dotazníků na posuzování e-learningu z tohoto pohledu (např. Quality on the line: benchmarks for success in Internet-based distance education, zmíněný projekt SEEQUEL) a některé jsou dokonce i z českého prostředí; napřr. Standarty evaluace z fakulty ekonomické ZČU v Plzni (Eger, 2005). Tento prŕstup evaluace elearningového pohlíží na celý proces vzdělávání jako na jednolitý celek a nediferencuje vlastní vzdělávací proces, jeho etapy, uspořádání a strukturu výukového obsahu či dokonce jeho formu.

\section{Současné př́istupy k evaluaci vzdělávacích materiálů určených pro distanční vzdělávání a e-learning}

Jiný př́stup evaluace e-learningu, se kterým se ztotožňuje i autor předložené stati, potom vychází z faktu, že je možné posuzovat a evaluovat jednotlivé stavební kameny elearningového vzdělávání, kde jedním se základních jsou distanční studijní texty. I v tomto pojetí hodnocení e-learnigu byla vypracována celá řada studií a realizována i výzkumná šetření, která se zaměřovala na standardy kvality dílčích částí e-learningu. Ze zahraniční produkce jsou velmi zajímavé práce M. Simonsona, S. Smaldina, M. Allbrighta a J. Frydengerga (Frydengerg, 2002). Z domácí produkce je možné zmínit především publikace K. Květoně, L. Koníčka, D. Bauerové (Bauerová, 2007), E. Mechlové, J. Šarmanové a M. Malčíka. Poslední tři jmenovaní ve své publikaci „Podpora akreditace distančního vzdělávání formou e-learningu“ (Mechlová, Šarmanová, \& Malčík, 2008) při posuzování výukových opor využívaných pro tento způsob výuky, vymezují základní čtyři oblasti:

- základní vlastnosti textu,

- aktivizace studujících,

- plánování a organizace studijních aktivit,

- zpětná vazba a hodnocení.

I když je toto pojetí evaluace elektronického distančního studijního textu velmi vhodné a vyvážené, neakcentuje některé moderní trendy v realizaci e-learningu s využitím jeho vyšších složek jako e-twinnig či virtualizace. Tyto vzdělávací strategie, které jsou založeny na zejména psychomotorických a afektivních cílech edukace, se v dnešní době dostávají do popředí zájmu jak studentů (Marešová, 2009), tak i učitelů. 


\section{Návrh optimalizovaného systému hodnocení vzdělávacích materiálů určených pro distanční vzdělávání a e-learning}

Při vlastním návrhu a konstrukci optimalizovaného systému hodnocení vzdělávacích materiálů určených pro distanční vzdělávání a e-learning vycházíme z předpokladů, které je možné vyvodit z výše uvedených skutečností.

- Klasické pojetí distančního vzdělávání vychází z toho, že hlavním nosičem informací (znalostí, dovedností, postojů apod.) je především text a to ve formě distančního studijního textu (častěji také studijní opory).

- E-learning umožňuje využít při výuce elektronické distanční studijní texty (častěji také elektronické studijní opory), které obsahují několik nosičů vzdělávacího obsahu, které jsou velmi často multimediálního charakteru.

- E-twinning umožňuje rozvinout oblast dosahování psychomotorických cílů vzdělávání pomocí e-learningu o experimentální činnost ve virtuálních laboratořích a simulacích.

- Při použití výše uvedených forem distanční výuky je nutné volit vhodnou vzdělávací strategii, která odráží možnosti využití specifického nosiče vzdělávacího obsahu, který by měl odpovídat dosahovaným cílům.

Na základě těchto předpokladů je tedy možné navrhnout optimalizovaný systém hodnoticích kritérií, které je možné rozdělit do těchto šesti základních oblastí, které respektují výše uvedené předpoklady:

- kritéria zaměřená na osobnost studenta a DiV,

- kritéria zaměřená na učení studenta a DiV,

- kritéria zaměřená na vzdělávací obsah a jeho formu s ohledem na DiV,

- kritéria zaměřená na specifika DiV,

- kritéria zaměřená na technické aspekty DiV a LMS,

- kritéria zaměřená na ergonomické aspekty DiV a LMS.

Jednotlivé oblasti optimalizovaného systému hodnocení vzdělávacích materiálů určených pro distanční vzdělávání a e-learning jsou naplněny celkem 78 hodnotícími kritérii vzniklými na základě teoretické analýzy, které vymezují jednotlivé vlastnosti, chování, fungování, obsah či strukturu posuzované součásti vzdělávacího materiálu.

\section{Ověřování optimalizovaného systému hodnocení vzdělávacích materiálů určených pro distanční vzdělávání a e-learning na základě výzkumného šetření}

Popsaný optimalizovaný systém hodnocení byl podroben statistické analýze zaměřené na ověření našeho výzkumného předpokladu: že optimalizovaný systém hodnocení vzdělávacích materiáli̊ určených pro distanční vzdělávání a e-learning je možné rozdělit do 6 základních skupin hodnotícich kritérií. Tento předpoklad jsme dokazovali pomocí multivariačních (vícerozměrných) statistických metod, shlukové a faktorové analýzy. Výzkumný vzorek tohoto šetření tvořilo celkem 734 studentů Pedagogické fakulty UP v Olomouci, kteří absolvovali výuku, v rámci prezenčních i kombinovaných forem studia. Strukturu výzkumného vzorku uvádí následující tabulka číslo 1. 
Tabulka 1

Struktura výzkumného vzorku

\begin{tabular}{|c|c|c|c|c|c|}
\hline \multicolumn{6}{|c|}{$\begin{array}{l}\text { Struktura výzkumného vzorku } \\
\text { n }=734\end{array}$} \\
\hline \multicolumn{2}{|c|}{ Pohlaví } & \multicolumn{2}{|c|}{ Věková struktura } & \multicolumn{2}{|c|}{$\begin{array}{l}\text { Spokojenost s distanční } \\
\text { výukou formou e-learningu }\end{array}$} \\
\hline \multirow[b]{2}{*}{ Ženy } & \multirow[b]{2}{*}{$569(78 \%)$} & 15-30 let & $528(72 \%)$ & \multirow[b]{2}{*}{ Ano } & \multirow[b]{2}{*}{$631(86 \%)$} \\
\hline & & 30-45 let & $146(20 \%)$ & & \\
\hline Muži & $165(22 \%)$ & $45-60$ let & $60(8 \%)$ & $\mathrm{Ne}$ & $103(14 \%)$ \\
\hline
\end{tabular}

\section{Výsledky výzkumného šetření zaměřeného ověření systému hodnocení}

Prvním provedeným krokem při ověřování výše uvedeného výzkumného předpokladu byla shluková analýza, která analyzovala hodnocení jednotlivých evaluačních kritérií respondenty. Výsledek této analýzy prezentuje níže uvedený trásňový graf na obrázku 1.

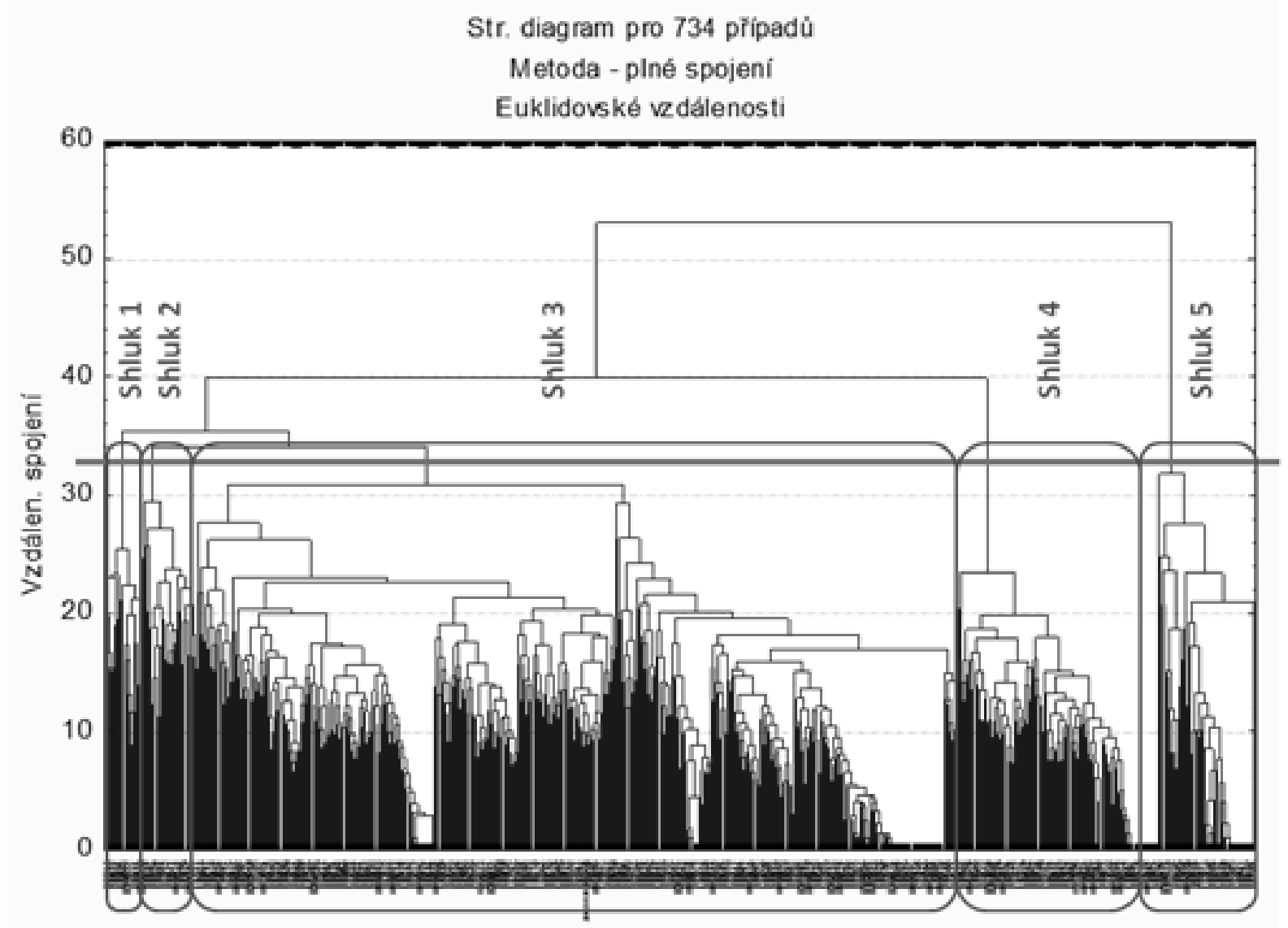

Obrázek 1. Shluková analýza hodnocení evaluačních kritérií studenty

Z provedené shlukové analýzy vyplynulo, že studenti se podle míry podobnosti hodnocení jednotlivých kritérií dají rozdělit do 5 základních skupin. Proto jsme provedli další shlukovou analýzu zaměřenou na skutečnost, zda je možné stejným způsobem rozdělit jednotlivá 
hodnotící kritéria do 6 základních skupin dle stanoveného výzkumného předpokladu. Výsledky této části shlukové analýzy prezentuje níže uvedený třásňový graf na obrázku 2.

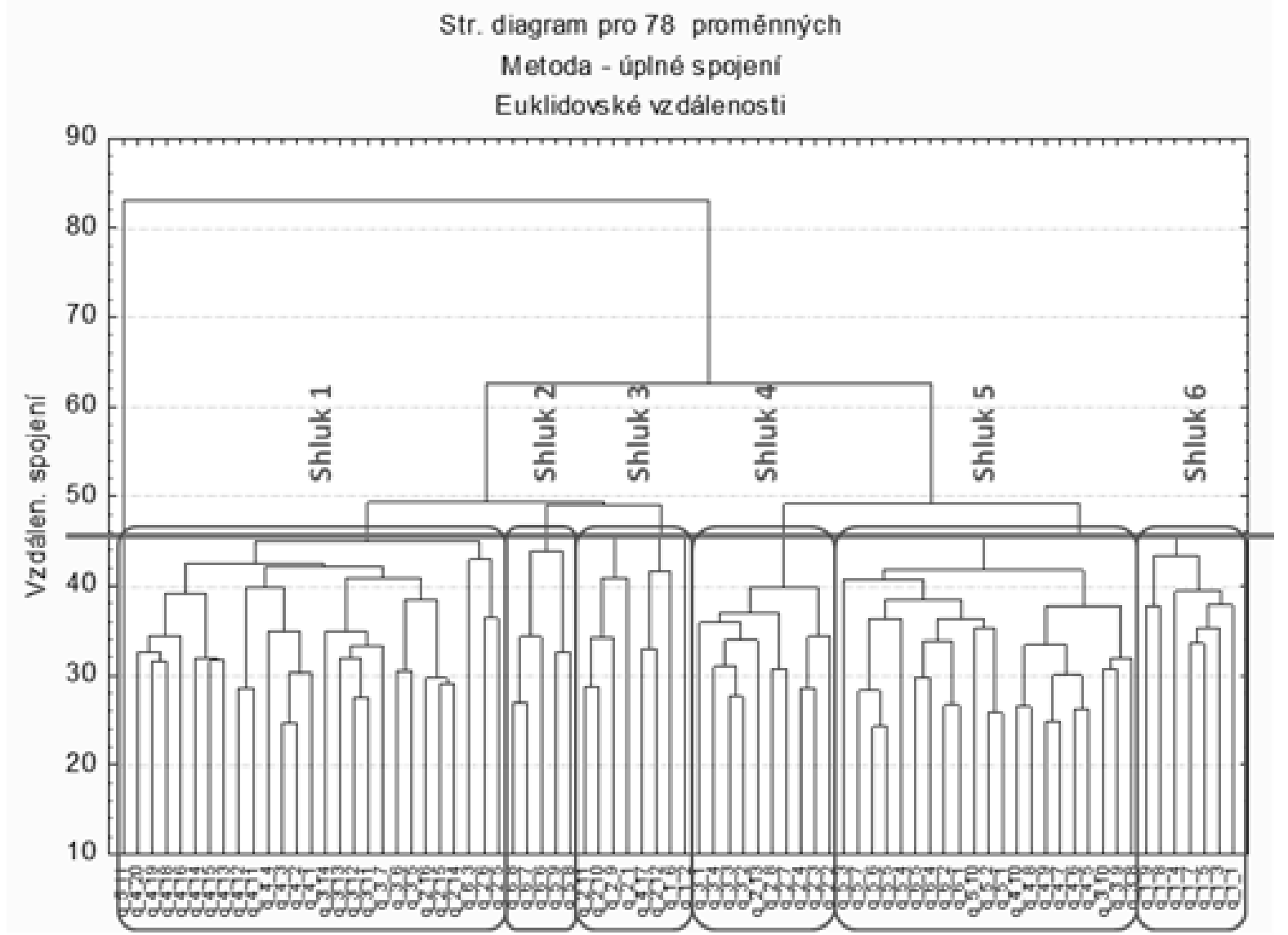

Obrázek 2. Shluková analýza hodnocení evaluačních kritérií

Jak ukazuje výše uvedený obrázek, je opravdu možné hodnotící kritéria rozdělit do šesti základních oblastí hodnocení. Dále je možné doložit toto tvrzení provedenou faktorovou analýzou, kdy byl na základě počtu vlastních čísel větších než 1 určen počet extrahovaných faktorů také na hodnotu 6 , což opět odpovídá výše uvedenému výzkumnému předpokladu. Výsledky této dílčí části faktorové analýzy jsou prezentovány v níže uvedené tabulce číslo 2.

Tabulka 2

Vlastni čísla a faktory objasněná procenta rozptylu

\begin{tabular}{|c|c|c|c|c|}
\hline \multirow{2}{*}{ Faktor } & \multicolumn{4}{|c|}{ Vlastní čísla (Spearmanovy korelace, Počet proměnných - 42) } \\
\cline { 2 - 5 } & Vlastní číslo & $\begin{array}{c}\text { \% celkového } \\
\text { rozptylu }\end{array}$ & $\begin{array}{c}\text { Kumulativní } \\
\text { vlastní číslo }\end{array}$ & $\begin{array}{c}\text { Kumulativní \% } \\
\text { rozptylu }\end{array}$ \\
\hline 1 & 17,50 & $\mathbf{4 1 , 6 6}$ & 17,50 & $\mathbf{4 1 , 6 6}$ \\
\hline 2 & 3,12 & $\mathbf{7 , 4 2}$ & 20,61 & $\mathbf{4 9 , 0 8}$ \\
\hline 3 & 1,71 & $\mathbf{4 , 0 6}$ & 22,32 & $\mathbf{5 3 , 1 4}$ \\
\hline 4 & 1,64 & $\mathbf{3 , 9 2}$ & 23,96 & $\mathbf{5 7 , 0 5}$ \\
\hline 5 & 1,37 & $\mathbf{3 , 2 7}$ & 25,33 & $\mathbf{6 0 , 3 2}$ \\
\hline 6 & 1,25 & $\mathbf{2 , 9 8}$ & 26,59 & $\mathbf{6 3 , 3 0}$ \\
\hline
\end{tabular}


Šest extrahovaných faktorů vysvětluje celkem 63,30 \% celkového rozptylu hodnocení a je tedy možné konstatovat, že námi stanovený výzkumný předpoklad můžeme s určitými výhradami přijmout.

\section{Závěr}

Na základě teoretické analýzy používaných systémů evaluace e-learningových a distančních vzdělávacích kurzů či textů jsme dospěli k závěru, že stávající systémy hodnocení, které jsou založeny především na posuzování textových vlastností, nejsou vždy nejvhodnější, nebot' neakcentují některé modernizační trendy. Byl tedy navržen a vytvořen optimalizovaný systém hodnocení vzdělávacích materiálů určených pro distanční vzdělávání a e-learning. Takto vytvořený systém hodnocení byl ověřován na základě vícerozměrných statistických metod. Je tedy možné konstatovat, že navržený optimalizovaný systém hodnocení vzdělávacích materiálů určených pro distanční vzdělávání a e-learning, se při použití vícerozměrných statistických metod ukázal jako správný. I když se nám podařilo navržený systém hodnocení elektronických studijních opor pomocí statistických metod prokázat, musíme v zájmu objektivity konstatovat, že uvedené výzkumné šetření zatím proběhlo pouze v rámci jedné vzdělávací instituce. Výzkumné šetření tedy bude pokračovat, a to v rámci řešení projektu GAČR č. P407/11/1306, kdy budeme i nadále pokračovat ve sběru dalších výzkumných dat, která po získání dostatečného počtu odpovědí od respondentů z dalších 4 vysokých škol a vzdělávacích institucí podrobíme stejné vícerozměrné analýze.

\section{Literatura}

Anderson, J., \& McCormick, R. (2005). A common framework for e-learning quality. Dostupné z http://insight.eun.org/ww/en/pub/insight/ thematic_dossiers /articles/ quality_ criteria/equality $1 . h t m$

Bauerová, D. (2007). Větší pozornost než „e“ zasluhuje „learning“. In M. Drozdová (Ed.), Sborník přispěvků odborného semináře ELearn 2007 (pp. 263-266). Žilina: VŽU.

Bednaříková, I. (2008) Specifika učení dospělých - východisko pro kvalitní eLearning. In P. Poulová (Ed.), eLearning 2008 - sbornik př́spěvků z konference a soutěže (pp. 125-129). Hradec Králové: VUHK.

Blecharz, P., \& Zindulková, D. (2005). TQM. Ostrava: VŠP.

Eger, L. (2004). Evaluace e-learningu se zaměřením na pedagogickou stránku. In Z. Sládková (Ed.), E-learning - př́padová studie z projektu Comenius (pp. 1-74). Plzeň: ZČÚ.

Eger, L. (2005). Motivace v e-learningu. In E. Mazák (Ed.), E-learning forum 2005 (pp. 13-19). Plzeň: ZČU. Dostupné z http://www.e-univerzita.cz/old/2005/prezentace/eger.pdf

E-learner's guide to the selection and quality dialogue with e-learning providers. (2004). In Seequel 2004. Brusel: eLIG. Dostupné z http://www.education observatories.net/seequel/SEEQUEL_eLearners_user_guide.pdf

Frydenberg, J. (2002). Qualioty standards in e-Learning: A matrix of analysis. The International Review of Research in Open and Distance Learning 3(2), 114-126.

Kirkpatrick, D. (1998). Businessballs. Kirkpatric's learning and training evauation theory. Dostupné z http://www.businessballs.com/kirkpatricklearningevaluationmodel.htm

Marešová, H. (2009). E-learning v multiuživatelském virtuálním prostředí. Journal of Technology and Information Education, 1(1), 39-44. Dostupné z

http://www.jtie.upol.cz/clanky_1_2009/maresova.pdf

Mechlová, E., Šarmanová, J., \& Malčík, M. (2008). Podpora akreditace distančního vzdělávání formou e-learningu. In. L. Eger (Ed.), Česká asociace distančního univerzitního vzdělávání (pp. 27-41). Praha: ČADUV. Dostupné z http://rccv.vsb.cz/materialy/caduv08/

prispevky/prispevek_Mechlova.pdf 
Philips, J., \& Philips, P. (2001). The return on investment (ROI) process: Issues and trends. Dostupné $\mathrm{z}$ http://www.franklincovey.com

\section{Kontakt}

PhDr. Milan Klement, Ph.D.

Univerzita Palackého

Pedagogická fakulta, Katedra technické a informační výchovy,

Žižkovo nám. 5, 77140 Olomouc

e-mail: milan.klement@upol.cz

\section{Bibliografické údaje}

Klement, M. (2011). Možnosti hodnocení elektronických studijních opor. In T. Janík, P. Knecht, \& S. Šebestová (Eds.), Smíšený design v pedagogickém výzkumu: Sborník přispěvků z 19. výroční konference České asociace pedagogického výzkumu (s. 91-97). Brno: Masarykova univerzita.

Dostupné z: http://www.ped.muni.cz/capv2011/sbornikprispevku/klement.pdf

doi: $10.5817 /$ PdF.P210-CAPV-2012-25 